\title{
Body mass index and lung cancer risk: a pooled analysis based on nested case- control studies from four cohort studies
}

\author{
Harinakshi Sanikini', Jian-Min Yuan, ${ }^{2,3}$, Lesley M. Butler ${ }^{2,3}$, Woon-Puay Koh ${ }^{4,5}$, Yu-Tang Gao ${ }^{6,7}$, Annika Steffen ${ }^{8}$, \\ Mattias Johansson ${ }^{9}$, Paolo Vineis ${ }^{10}$, Gary E. Goodman ${ }^{11}$, Matt J. Barnett ${ }^{11}$, Rayjean J. Hung ${ }^{12}$, Chu Chen ${ }^{13}$ \\ and Isabelle Stücker ${ }^{1 *}$
}

\begin{abstract}
Background: Obesity has been proposed as a potential protective factor against lung cancer. We examined the association between BMI and lung cancer risk in a pooled analysis based on nested case-control studies from four cohort studies.

Methods: A case-control study was nested within four cohorts in USA, Europe, China and Singapore that included 4172 cases and 8471 control subjects. BMI at baseline was calculated as weight in kilograms divided by height in meters squared $\left(\mathrm{kg} / \mathrm{m}^{2}\right)$, and classified into 4 categories: underweight (BMl $\left.<18.5\right)$, normal weight $(18.5 \leq \mathrm{BMl}<25)$, overweight $(25 \leq \mathrm{BMI}<30)$ and obese $(\geq 30)$. Odds ratios (ORs) and $95 \%$ confidence intervals (Cls) for BMI-lung cancer associations were estimated using unconditional logistic regression, adjusting for potential confounders.

Results: Considering all participants, and using normal weight as the reference group, a decreased risk of lung cancer was observed for those who were overweight (OR 0.77, 95\% Cl: 0.68-0.86) and obese (OR 0.69, 95\% Cl: 0.590.82). In the stratified analysis by smoking status, the decreased risk for lung cancer was observed among current, former and never smokers ( $P$ for interaction 0.002). The adjusted ORs for overweight and obese groups were 0.79 (95\% Cl: 0.68-0.92) and 0.75 (95\% Cl: 0.60-0.93) for current smokers, 0.70 (95\% Cl: $0.53-0.93)$ and 0.55 (95\% Cl: $0.37-$ 0.80 ) for former smokers, 0.77 (95\% Cl: 0.59-0.99), and 0.71 (95\% Cl: 0.44-1.14) for never smokers, respectively. While no statistically significant association was observed for underweight subjects who were current smokers (OR 1.24, 95\% Cl: 0.98-1.58), former smokers (OR 0.27, 95\% Cl: 0.12-0.61) and never smokers (OR 0.83, 95\% Cl: 0.5.-1.28).

Conclusion: The results of this study provide additional evidence that obesity is associated with a decreased risk of lung cancer. Further biological studies are needed to address this association.
\end{abstract}

Keywords: Body mass index, Obesity, Overweight, Lung cancer

\section{Background}

Lung cancer is the most common cancer and the leading cause of cancer-related deaths worldwide, with an estimated 1.82 million lung cancer cases and 1.59 million deaths in 2012 [1]. Incidence and mortality rates for lung cancer are higher among men than women, with 1.2 million cases and 1 million deaths estimated in men and

\footnotetext{
* Correspondence: isabelle.stucker@inserm.fr

${ }^{1}$ Cancer and Environment Group, Center for Research in Epidemiology and Population Health (CESP), INSERM, Université Paris Saclay, Université Paris-Sud, Villejuif, France

Full list of author information is available at the end of the article
}

580,000 cases and 490,000 deaths estimated in women in 2012 [2]. The incidence of lung cancer varies by age, sex, geographical location and histological type [3, 4]. These variations are mostly determined by differences in smoking patterns and exposures to other lung carcinogens [5-8]. Smoking, second-hand smoke, air pollution, asbestos, radon, and occupational exposure to chemical carcinogens are well-known risk factors for lung cancer [9-13]. Furthermore, a comprehensive review of epidemiological evidence revealed that low consumption of fruits and vegetables contribute to an increased risk of lung cancer $[14,15]$. 
Obesity is linked to an increased risk of many cancers, including cancers of the breast (in post-menopausal women), endometrium, esophagus, gallbladder, kidney, colorectal, and pancreas [16]. By contrast, body mass index (BMI, a proxy measure of obesity) of $\geq 30 \mathrm{~kg} / \mathrm{m} 2$, has been inversely associated with the risk of lung cancer in several case-control and cohort studies [17-27]. Besides, some of these studies have also shown that low BMI is associated with an increased risk of lung cancer $[19,20,25,28,29]$. Two recent meta-analyses have provided more evidence supporting that excess weight could significantly decrease the risk of lung cancer [30, 31]. There are some methodological issues in examining the association between BMI and lung cancer risk. Firstly, smoking is an established risk factor for lung cancer and is also associated with body weight, which may confound the relation between BMI and lung cancer [32, 33]. Smokers tend to be leaner than non-smokers; heavy smokers tend to have greater body weight than light smokers, which likely reflects an unhealthy lifestyle (for instance, poor diet and low level of physical activity) [32]. In fact, studies that restricted the analysis to never smokers, the association between BMI and lung cancer disappeared [34, 35]. Secondly, preclinical effects of lung cancer and associated weight loss may distort the association between BMI and lung cancer, which is often referred to as reverse causation $[20,36]$. Studies that had a short follow-up or studies in which weight was reported shortly before cancer diagnosis are more prone to reverse causality. To our knowledge, few studies have attempted to tackle these methodological issues using Mendelian randomization approach [37-39]. However, this method has not been extended to evaluate nonlinear associations. Apart from these, some epidemiological studies have failed to find the inverse association between BMI and lung cancer risk [40, 41]. In addition, histological types of lung cancer may exemplify largely divergent diseases with different etiologies, but studies examining the association between BMI and lung cancer by histological type are limited [24, 42, 43].

Hence, the aim of the present study was to examine the association between BMI and lung cancer risk in a pooled analysis based on nested case-control studies from four cohort studies in USA, Europe, China and Singapore. The large sample size of this nested study allowed us to assess the association by gender, smoking status and histological types of lung cancer.

\section{Methods}

\section{Study population}

This project was conducted under the framework of the International Lung Cancer Consortium (ILCCO). ILCCO was established in 2004 with the objective to pool equivalent data and maximize resource sharing and statistical power of epidemiological studies of lung cancer [44]. Four ILCCO studies are included in this pooled analysis. The collaborating cohorts have been described in detail previously [45-51]. These are the Carotene and Retinol Efficacy Trial (CARET), European Prospective Investigation into Cancer and Nutrition Study (EPIC), Shanghai Cohort Study (SCS), and Singapore Chinese Health Study (SCHS). A summary of selected characteristics of these cohorts is presented in Table 1.

\section{Cases ascertainment and data collection method}

Cases included were all incident primary lung cancer (International Classification of Diseases-Oncology (ICDO) 3rd edition and included all invasive cancers coded to C33-34). All histological types were included. Case ascertainment varied among studies but included linking

Table 1 Characteristics of participating cohorts

\begin{tabular}{|c|c|c|c|c|c|c|c|c|}
\hline Study & Location & $\begin{array}{l}\text { Enrollment } \\
\text { years }\end{array}$ & $\begin{array}{l}\text { Baseline } \\
\text { cohort }\end{array}$ & $\begin{array}{l}\text { Age at } \\
\text { enrollment }\end{array}$ & $\begin{array}{l}\text { Follow-up } \\
\text { mean years }\end{array}$ & $\begin{array}{l}\text { Source of } \\
\text { height and } \\
\text { weight data }\end{array}$ & $\begin{array}{l}\text { Cases/Controls } \\
(N=4172 / 8471)\end{array}$ & Matching \\
\hline $\begin{array}{l}\text { Carotene and Retinol } \\
\text { Efficacy Trial }\end{array}$ & USA & 1985-1994 & 18,314 & $45-69$ & 11.5 & Measured & $787 / 1564$ & $\begin{array}{l}\text { Age ( } \pm 4 \text { years), sex, race, } \\
\text { enrollment year ( } 2 \text {-years } \\
\text { intervals), baseline measures } \\
\text { of smoking status (current } \\
\text { or former), asbestos exposure } \\
\text { (yes or no) and duration } \\
\text { of follow up }\end{array}$ \\
\hline $\begin{array}{l}\text { European Prospective } \\
\text { Investigation into } \\
\text { Cancer and Nutrition }\end{array}$ & Europe & $1992-2000$ & 521,468 & $35-70$ & 10.1 & $\begin{array}{l}\text { Mostly Measured, } \\
\text { except for some } \\
\text { EPIC centers }^{a}\end{array}$ & $1242 / 2622$ & $\begin{array}{l}\text { Age, sex, smoking status, } \\
\text { and country of recruitment }\end{array}$ \\
\hline $\begin{array}{l}\text { Shanghai Cohort } \\
\text { Study }\end{array}$ & China & 1986-1989 & 18,244 & $45-64$ & 15.8 & Self-reported & $965 / 1929$ & Age and sex \\
\hline $\begin{array}{l}\text { Singapore Chinese } \\
\text { Health Study }\end{array}$ & Singapore & 1993-1998 & 63,257 & $45-74$ & 10.0 & Self-reported & $1178 / 2356$ & Age and sex \\
\hline
\end{tabular}

${ }^{\mathrm{a}}$ Oxford cohort, Norwegian cohort and approximately two-thirds of the French cohort, height and weight were self-reported 
participants to cancer registries, health insurance records, medical records, self-report, and next of kin reports. Most of the cases among studies were histologically confirmed.

In each study, two lung cancer-free controls were matched per case (controls were cancer-free at the time of diagnosis of the matched case). Mostly, controls were matched to cases on age (plus/minus 5 years) and sex. Some cohorts used more stringent matching on other variables (Table 1). In each study, two lung cancer-free controls were matched per case.

Data on demographics and possible confounders were collected among studies through a self-administered written questionnaire (EPIC and CARET) or in- person interviews (EPIC, SCS and SCHS). At recruitment, measurements of height and weight were taken for all the participants of the CARET study and for most of the EPIC cohort (Table 1). In the SCS and SCHS cohort and for some of the EPIC participants (mainly for Oxford cohort, Norwegian cohort and approximately two-thirds of the French cohort) height and weight at baseline were self-reported. A detailed description of data collection methods has been published previously by the individual studies [45-51]. From each study, baseline information on anthropometric measurements (height and weight), history of cigarette smoking, sex, age at enrollment and diagnosis, year of last observation/follow-up, and level of education was requested.

\section{Statistical analysis}

Unconditional logistic regression models were used to estimate odds ratios (ORs) and 95\% confidence intervals (CIs) for the association between BMI and lung cancer risk. BMI at baseline was calculated as weight in kilograms divided by the square of the height in meters $\left(\mathrm{kg} / \mathrm{m}^{2}\right)$ and classified into 4 categories according to the WHO international classification: underweight $(\mathrm{BMI}<18.5)$, normal weight $(18.5 \leq \mathrm{BMI}<25)$, overweight $(25 \leq \mathrm{BMI}<30)$ and obese $(\geq 30)$. Normal weight was used as the reference category. Pack-years of smoking were computed by using the formula: (number of years smoked $x$ mean number of cigarettes smoked per day)/20. In cases, time elapsed was computed as the difference between the age at enrolment and diagnosis, whereas in controls, it was calculated as the difference between age at enrolment and last follow-up/ observation.

All models were adjusted for sex, study center, age $(<45$, $45-49,50-54,55-59,60-64,65-69, \geq 70)$, time elapsed $(<2,2-8,9-14,15-20, \geq 20)$, pack-years of smoking $(0,<$ $20,20-29,30-39,40-49$, and $\geq 50$ ), and education level (none, primary school, middle/vocational, secondary school, postsecondary/technical and university). Subgroup analyses were performed for gender, smoking status and histologic types of lung cancer. Deviation of multiplicative interactions of BMI with sex and smoking status was explored by including an interaction term along with the main effect term in the adjusted model. The statistical significance of the interaction term was evaluated using likelihood ratio tests. To investigate possible reverse causation, sensitivity analysis was performed by excluding lung cancer cases diagnosed in the first 3 years of follow up. Additional, sensitivity analysis was also conducted by eliminating two studies (SCS and SCHS), where height and weight were self-reported. We tested for heterogeneity across studies using the $\mathrm{Q}$ and $\mathrm{I}^{2}$ statistic [52]. To graphically display odds ratios representing the doseresponse association for BMI and lung cancer risk, we used the restrictive cubic spline (RCS) function with 4 knots $(5,10,20$, and 40 percentile) in a multivariate unconditional logistic regression model as described above. The selection of model (4 knots) was based on the lower Akaike Information Criteria (AIC). This analysis was performed using the RCS_Reg SAS Macro created by Desquilbet and Mariotti [53]. All analyses were performed using the SAS 9.3 software (SAS Institute, Cary, NC) and a $p$-value $<0.05$ was considered as statistically significant.

\section{Results}

The study included 4172 lung cancer cases and 8471 controls aged 35 to 74 years (Table 1). Baseline characteristics of participants are presented in Table 2. Of the 4172 lung cancer cases, 3043 were men and 1129 were women. Compared with controls, cases were slightly older, had a lower education level and higher prevalence of current smoking. The average age at lung cancer onset in cases was 68.0 years, and the average time elapsed from enrollment to diagnosis of lung cancer in cases was 8.3 years.

In the total participants, cases had slightly lower mean weight compared with controls (68.2 and $69.7 \mathrm{~kg}$ ). Mean height was similar $(1.67 \mathrm{~m})$. Fifty-two percent of cases and $51 \%$ of controls had BMI in the normal range, $27 \%$ of cases and $32 \%$ of controls were overweight, and $9 \%$ of cases and $11 \%$ of controls were obese.

Table 3 displays adjusted ORs and 95\% CIs for lung cancer according to baseline BMI categories. Considering all participants, and using normal weight as the reference group, a decreased risk of lung cancer was observed for those who were overweight (OR 0.77, 95\% CI: $0.68-0.86$ ) and obese (OR 0.69, 95\% CI: 0.59-0.82) whereas no statistically significant association was observed for underweight subjects (OR 1.03, 95\% CI: 0.841.25). When stratified by gender, the inverse association observed between BMI and lung cancer risk was similar for overweight and obese men (OR 0.71, 95\% CI: $0.62-$ 0.81 for overweight group; and OR 0.63 , 95\% CI: $0.52-$ 0.78 for obese group); the association for women was slightly attenuated (OR 0.80, 95\% CI: 0.63-1.02 for 
Table 2 Selected characteristics of participants

\begin{tabular}{|c|c|c|c|}
\hline Characteristic & $\begin{array}{l}\text { Cases } \\
(n=4172) \\
\mathrm{N}(\%)\end{array}$ & $\begin{array}{l}\text { Controls } \\
(n=8471) \\
\mathrm{N}(\%)\end{array}$ & $P$ value $\left(X^{2}\right)$ \\
\hline Sex & & & 0.37 \\
\hline Men & $3043(72.9)$ & $6135(72.4)$ & \\
\hline Women & $1129(27.1)$ & $2336(27.6)$ & \\
\hline Age & & & $<.0001$ \\
\hline$<45$ & $76(1.8)$ & $197(2.3)$ & \\
\hline $45-49$ & $211(5.1)$ & $980(11.6)$ & \\
\hline $50-54$ & $602(14.4)$ & $1720(20.3)$ & \\
\hline $55-59$ & $1010(24.2)$ & $2165(25.5)$ & \\
\hline $60-64$ & $1216(29.2)$ & $2024(23.9)$ & \\
\hline $65-69$ & $731(17.5)$ & $1070(12.6)$ & \\
\hline$\geq 70$ & $326(7.8)$ & $324(3.8)$ & \\
\hline BMI $\left(\mathrm{kg} / \mathrm{m}^{2}\right)^{\mathrm{a}}$ & & & $<.0001$ \\
\hline Underweight & $250(5.9)$ & $408(4.8)$ & \\
\hline Normal weight & $2150(51.5)$ & $4276(50.5)$ & \\
\hline Overweight & $112(26.7)$ & $2746(32.4)$ & \\
\hline Obese & $373(8.9)$ & $934(11.0)$ & \\
\hline Missing & $287(6.9)$ & $107(1.3)$ & \\
\hline Education & & & $<.0001$ \\
\hline None & $529(12.7)$ & $699(8.3)$ & \\
\hline Primary & $1515(36.3)$ & $2518(29.7)$ & \\
\hline Middle/Nocational & $851(20.4)$ & $2109(24.9)$ & \\
\hline Secondary & $457(11.0)$ & $1060(12.5)$ & \\
\hline Postsecondary/Technical & $312(7.5)$ & $665(7.9)$ & \\
\hline University & $381(9.1)$ & $1164(13.7)$ & \\
\hline Unknown/not specified & $26(0.6)$ & $51(0.6)$ & \\
\hline Missing & $101(2.4)$ & $205(2.4)$ & \\
\hline Smoking status & & & $<.0001$ \\
\hline Never & $571(13.7)$ & $3144(37.1)$ & \\
\hline Former & $694(16.6)$ & $1735(20.5)$ & \\
\hline Current & $2892(69.3)$ & $3556(42.0)$ & \\
\hline Missing ${ }^{b}$ & $15(0.36)$ & $36(0.4)$ & \\
\hline Pack-years of smoking & & & $<.0001$ \\
\hline 0 & $571(13.7)$ & $3144(37.1)$ & \\
\hline$<20$ & $547(13.1)$ & $1562(18.4)$ & \\
\hline $20-29$ & $554(13.3)$ & $850(10.0)$ & \\
\hline $30-39$ & $691(16.6)$ & $891(10.5)$ & \\
\hline $40-49$ & $817(19.6)$ & $829(9.8)$ & \\
\hline$\geq 50$ & $831(19.9)$ & $892(10.5)$ & \\
\hline Missing & $161(3.9)$ & 303 (3.6) & \\
\hline \multicolumn{4}{|c|}{ Age at diagnosis of lung cancer, $y$} \\
\hline Mean (SD) & $68.0(8.1)$ & - & \\
\hline Median (range) & $68.2(38.1-91.0)$ & & \\
\hline
\end{tabular}

Table 2 Selected characteristics of participants (Continued)

\begin{tabular}{lll}
\hline Characteristic & $\begin{array}{l}\text { Cases } \\
(n=4172) \\
\mathrm{N}(\%)\end{array}$ & $\begin{array}{l}\text { Controls } \\
(n=8471) \\
\mathrm{N}(\%)\end{array}$ \\
\hline $\begin{array}{l}\text { Time elapsed, y } \\
\text { Mean (SD) }\end{array}$ & $P$ value $\left(\mathrm{X}^{2}\right)$ \\
$\quad \begin{array}{l}\text { Median (range) } \\
\text { Histological Type }\end{array}$ & $7.3(0-27)^{\mathrm{c}}$ & $13.3(5.1)^{\mathrm{d}}$ \\
Adenocarcinoma & $13.0(0-28)$ \\
Squamous cell carcinoma & $897(32.6)$ & \\
Large cell carcinoma & $221(7.9)$ & \\
Small cell carcinoma & $473(17.1)$ & \\
\hline
\end{tabular}

anderweight (BMI $<18.5)$, normal weight $(18.5 \leq \mathrm{BMI}<25)$, overweight $(25 \leq$ $\mathrm{BMI}<30)$ and obese $(\mathrm{BMI} \geq 30)$

${ }^{\text {b}}$ Subjects who had missing cigarettes smoked per day and duration of smoking

'Period between enrollment and diagnosis

dPeriod between enrollment and last follow-up/observation

overweight group; and OR 0.70, 95\% CI: $0.51-0.97$ for obese group) (Table 3 ).

To further investigate the association between BMI and lung cancer risk among subgroups, we stratified the analyses by smoking status (Table 4 ). In both genders combined, the decreased risk for lung cancer was observed among current, former, and never smokers ( $\mathrm{P}$ for interaction 0.002). The adjusted ORs for overweight and obese groups were 0.79 (95\% CI: $0.68-0.92)$ and 0.75 (95\% CI: 0.60-0.93) for current smokers, 0.70 (95\% CI: $0.53-$ $0.93)$ and 0.55 (95\% CI: $0.37-0.80)$ for former smokers, 0.77 (95\% CI: $0.59-0.99)$, and 0.71 (95\% CI: 0.44-1.14) for never smokers, respectively. When separate analysis was performed by gender, the decreased risk for lung cancer was observed among both former and current male and female smokers but it did not reach statistical significance among female smokers, which could be explained by few number of female cases (Table 4).

We performed RCS regression to describe the nonlinear dose-response association between BMI and risk of lung cancer (Fig. 1). In all the participants, we found a significant nonlinear dose-response association between $\mathrm{BMI}$ and risk of lung cancer ( $\mathrm{P}$ nonlinearity 0.001 ; Fig. 1a). After stratifying by gender, the evidence of a nonlinear association was observed in men ( $\mathrm{P}$ nonlinearity 0.009 ; Fig. $1 \mathrm{~b})$ but not in women ( $\mathrm{P}$ nonlinearity 0.11 ; Fig. 1c). After stratifying by smoking status, the nonlinear association was observed in former and current smokers $(\mathrm{P}$ nonlinearity 0.006; Fig. 1d,e respectively) but not in never smokers ( $\mathrm{P}$ nonlinearity 0.14 ; Fig. 1f).

We also examined the association between BMI and risk of histological types of lung cancer (Table 5). When we stratified the analysis by histological types, the reduction in risk was observed for all histological types but it was statistically significant for adenocarcinoma and large 
Table 3 Adjusted odds ratio of lung cancer according to BMl categories

\begin{tabular}{|c|c|c|c|c|c|c|c|c|c|}
\hline \multirow[b]{2}{*}{ BMI $\left(\mathrm{kg} / \mathrm{m}^{2}\right)^{\mathrm{a}}$} & \multicolumn{3}{|c|}{ Men and Women } & \multicolumn{3}{|l|}{ Men } & \multicolumn{3}{|l|}{ Women } \\
\hline & $\begin{array}{l}\text { Cases } \\
(N=4172)\end{array}$ & $\begin{array}{l}\text { Controls } \\
(N=8471)\end{array}$ & $\begin{array}{l}\text { Adjusted } \\
\text { OR }(95 \% \mathrm{Cl})^{\mathrm{b}}\end{array}$ & $\begin{array}{l}\text { Cases } \\
(N=3043)\end{array}$ & $\begin{array}{l}\text { Controls } \\
(N=6135)\end{array}$ & $\begin{array}{l}\text { Adjusted } \\
\text { OR }(95 \% \mathrm{Cl})^{c}\end{array}$ & $\begin{array}{l}\text { Cases } \\
(N=1129)\end{array}$ & $\begin{array}{l}\text { Controls } \\
(N=2336)\end{array}$ & $\begin{array}{l}\text { Adjusted } \\
\text { OR }(95 \% \mathrm{Cl})^{c}\end{array}$ \\
\hline Underweight & 250 & 408 & $1.03(0.84-1.25)$ & 196 & 310 & $1.06(0.85-1.32)$ & 54 & 98 & $0.85(0.52-1.39)$ \\
\hline Normal weight & 2150 & 4276 & Reference & 1607 & 3155 & Reference & 543 & 1121 & Reference \\
\hline Overweight & 1112 & 2746 & $0.77(0.68-0.86)$ & 810 & 2004 & $0.71(0.62-0.81)$ & 302 & 742 & $0.80(0.63-1.02)$ \\
\hline Obese & 373 & 934 & $0.69(0.59-0.82)$ & 256 & 628 & $0.63(0.52-0.78)$ & 117 & 306 & $0.70(0.51-0.97)$ \\
\hline Missing & 287 & 107 & - & 174 & 38 & - & 113 & 69 & - \\
\hline
\end{tabular}

anderweight $(\mathrm{BMI}<18.5)$, normal weight $(18.5 \leq \mathrm{BMI}<25)$, overweight $(25 \leq \mathrm{BMI}<30)$ and obese $(\mathrm{BMI} \geq 30)$

${ }^{\mathrm{b}}$ Adjusted for age, gender, study center, time elapsed, pack-years of smoking and education level

${ }^{c}$ Adjusted for age, study center, time elapsed, pack-years of smoking and education level

cell carcinoma. The adjusted ORs for overweight and obese groups were 0.74 (95\% CI: $0.62-0.87$ ) and 0.65 (95\% CI: $0.50-0.85)$ for adenocarcinoma, 0.69 (95\% CI: $0.48-0.99)$ and 0.49 (95\% CI: 0.26-0.92) for large cell carcinoma, respectively.

The risk estimates did not change substantially in the sensitivity analysis after exclusion of lung cancer cases diagnosed in the first 3 years of follow-up (Additional file 1: Table S1). In addition, analyses using measured BMI, which included two studies (CARET and EPIC) yielded similar results (data not shown).There was mild heterogeneity between cohorts for the BMI-lung cancer results $\left(P\right.$ value $\left.=0.12, \mathrm{I}^{2}=50 \%\right)$ (Additional file 2 : Figure S1).

\section{Discussion}

In this pooled analysis of cohorts involving 12,643 subjects (4172 lung cancer cases and 8471 controls), we found a statistically significant inverse, dose-dependent association between BMI and lung cancer risk. This inverse association was present in current, former and never smokers and the effect was more evident for the subjects with a BMI of $>30\left(\mathrm{~kg} / \mathrm{m}^{2}\right)$.

Table 4 Adjusted odds ratio of lung cancer by smoking status according to BMl categories

\begin{tabular}{|c|c|c|c|c|c|c|c|c|c|}
\hline \multirow[t]{2}{*}{ BMI $\left(\mathrm{kg} / \mathrm{m}^{2}\right)^{\mathrm{a}}$} & \multirow[b]{2}{*}{ Cases } & \multicolumn{2}{|c|}{ Men and Women } & \multirow[b]{2}{*}{ Cases } & \multicolumn{2}{|l|}{ Men } & \multirow[b]{2}{*}{ Cases } & \multicolumn{2}{|l|}{ Women } \\
\hline & & Controls & Adjusted OR $(95 \% \mathrm{Cl})^{\mathrm{b}}$ & & Controls & $\overline{\text { Adjusted OR }(95 \% \mathrm{Cl})^{c}}$ & & Controls & $\overline{\text { Adjusted OR }(95 \% \mathrm{Cl})^{c}}$ \\
\hline \multicolumn{10}{|l|}{ Never Smokers } \\
\hline Underweight & 33 & 161 & $0.83(0.53-1.28)$ & 15 & 97 & $0.88(0.49-1.60)$ & 18 & 64 & $0.84(0.42-1.68)$ \\
\hline Normal weight & 334 & 1794 & Reference & 169 & 1159 & Reference & 165 & 635 & Reference \\
\hline Overweight & 117 & 916 & $0.77(0.59-0.99)$ & 46 & 540 & $0.74(0.51-1.06)$ & 71 & 376 & $0.75(0.51-1.11)$ \\
\hline Obese & 29 & 233 & $0.71(0.44-1.14)$ & 5 & 110 & $0.55(0.22-1.40)$ & 24 & 123 & $0.73(0.40-1.36)$ \\
\hline Missing & 58 & 40 & - & 19 & 15 & - & 39 & 25 & - \\
\hline \multicolumn{10}{|l|}{ Former Smokers } \\
\hline Underweight & 10 & 58 & $0.27(0.12-0.61)$ & 8 & 51 & $0.26(0.11-0.61)$ & 2 & 7 & $0.27(0.02-3.69)$ \\
\hline Normal weight & 262 & 609 & Reference & 203 & 477 & Reference & 59 & 132 & Reference \\
\hline Overweight & 272 & 729 & $0.70(0.53-0.93)$ & 224 & 599 & $0.66(0.48-0.91)$ & 55 & 130 & $0.77(0.36-1.65)$ \\
\hline Obese & 105 & 297 & $0.55(0.37-0.80)$ & 83 & 230 & $0.51(0.33-0.79)$ & 22 & 67 & $0.67(0.27-1.67)$ \\
\hline Missing & 38 & 42 & & 26 & 15 & - & - & 27 & - \\
\hline \multicolumn{10}{|l|}{ Current Smokers } \\
\hline Underweight & 207 & 189 & $1.24(0.98-1.58)$ & 173 & 162 & $1.26(0.98-1.63)$ & 34 & 27 & $0.82(0.38-1.76)$ \\
\hline Normal weight & 1549 & 1860 & Reference & 1234 & 1511 & Reference & 315 & 349 & Reference \\
\hline Overweight & 710 & 1085 & $0.79(0.68-0.92)$ & 537 & 853 & $0.75(0.63-0.88)$ & 173 & 232 & $0.87(0.62-1.23)$ \\
\hline Obese & 237 & 400 & $0.75(0.60-0.93)$ & 167 & 286 & $0.72(0.55-0.92)$ & 70 & 114 & $0.73(0.46-1.15)$ \\
\hline Missing & 189 & 22 & - & 127 & 6 & - & 62 & 16 & - \\
\hline
\end{tabular}

anderweight $(\mathrm{BMI}<18.5)$, normal weight $(18.5 \leq \mathrm{BMI}<25)$, overweight $(25 \leq \mathrm{BMI}<30)$ and obese $(\mathrm{BMI} \geq 30)$

${ }^{\mathrm{b}}$ Adjusted for age, gender, study center, time elapsed, pack-years of smoking (except for never smokers) and education level

${ }^{c}$ Adjusted for age, study center, time elapsed, pack-years of smoking (except for never smokers) and education level 


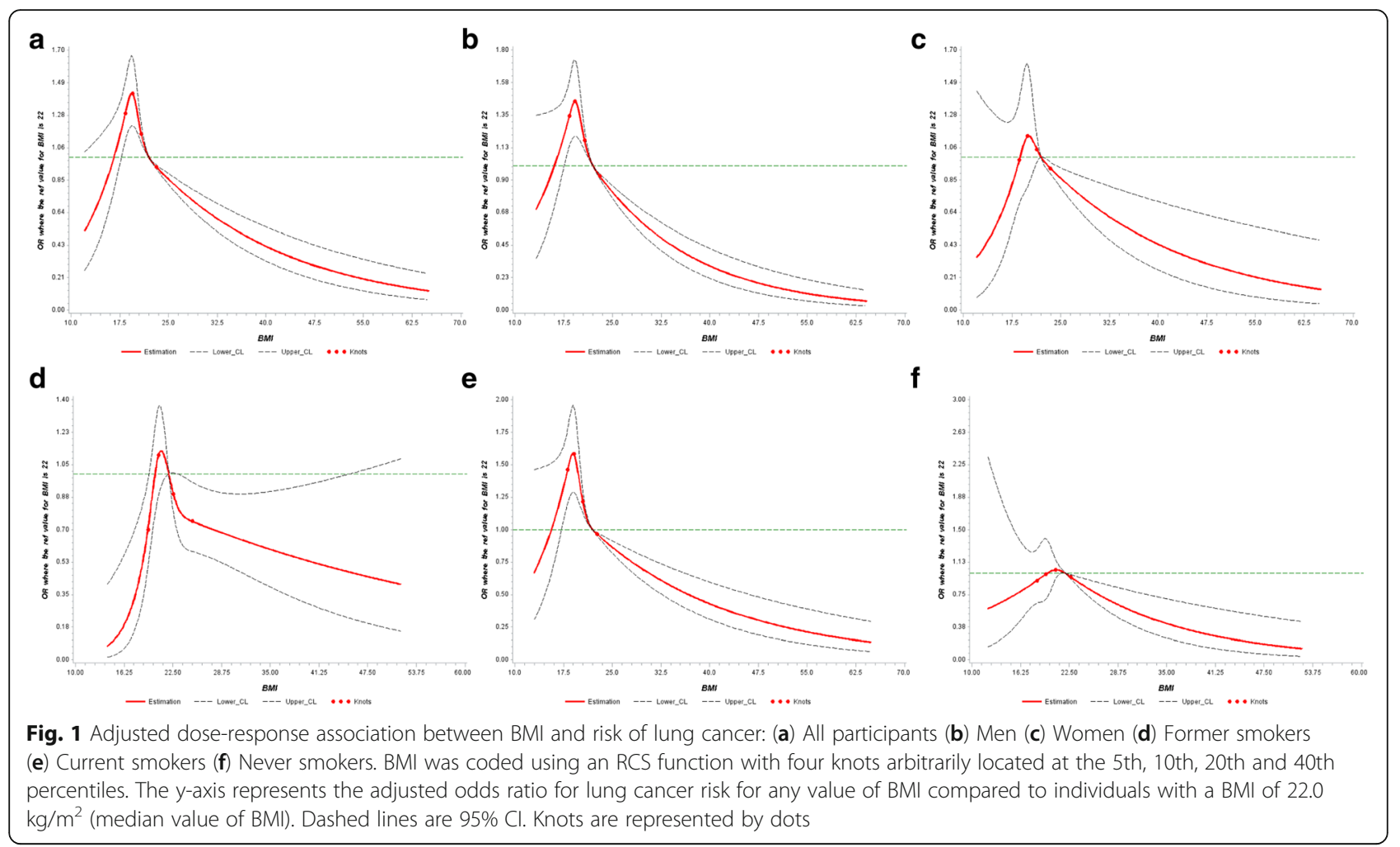

Our study found that being overweight or obese is associated with a decreased risk of lung cancer. This is consistent with a recent meta-analysis including 31 studies (20 cohorts, 11 case-control). The pooled relative risks in this study were 0.74 (95\% CI: $0.68-0.80$ ) for overweight (BMI $25-29.9 \mathrm{~kg} / \mathrm{m}^{2}$ ) and 0.71 (95\% CI: 0.68-0.80) for obese (BMI $\geq 30 \mathrm{~kg} / \mathrm{m}^{2}$ ), compared with normal weight (BMI $18.5-24.9 \mathrm{~kg} / \mathrm{m}^{2}$ ) [30]. More recently Duan et al. conducted a dose-response metaanalysis, which included 29 cohort studies and found evidence of a non-linear association between BMI and lung cancer risk ( $\mathrm{P}$ nonlinearity $<0.001$ ) [31]. Compared with individuals with a BMI of $18.5-24.9 \mathrm{~kg} / \mathrm{m}^{2}$, the summary relative risks for those with a BMI of $30 \mathrm{~kg} / \mathrm{m}^{2}$ and BMI $35 \mathrm{~kg} / \mathrm{m}^{2}$ were 0.91 (95\% CI: $\left.0.85-0.98\right)$ and 0.81 (95\% CI: 0.72-0.91), respectively [31]. A cohort study conducted in the UK, which was not included in this meta-analysis, also showed an inverse association between higher BMI and lung cancer risk [54].

In gender-stratified analysis, we observed similar results in both men and women. The findings of previous meta-analyses also indicated no gender differences in the association between BMI and lung cancer risk [30, 31].

Given that smoking is the most important risk factor for lung cancer and associated with body weight, we stratified our analyses by smoking status and found a significant inverse association between BMI and lung cancer risk among current, former and never smokers. This is in line with results of previous meta-analysis [31]. In this meta-analysis, the pooled RRs for overweight and obese groups were 0.91 (95\% CI: 0.85-0.98) and 0.77 (95\% CI: 0.69-0.85) for ex-smokers, 0.79 (95\% CI: $0.71-0.87$ ), 0.72 (95\% CI: 0.66-0.78) for current smokers and 0.86 (95\% CI: $0.78-0.94)$ and 0.86 (95\% CI: 0.75-0.98) for non-smokers respectively [31].

In our study, stratification by histological subtype showed that overweight and obese was significantly inversely associated with risk of adenocarcinoma and large cell carcinoma. The results of stratified analysis in the previous meta-analysis reported a lower risk for adenocarcinoma and squamous cell carcinoma [30, 31].

Our study found no association between being underweight and risk of lung cancer. However, stratification by smoking status showed a non-significant increased risk for lung cancer in current smokers who were underweight (OR 1.24, 95\% CI: 0.98-1.58). Results of a recent meta-analysis reported a significant positive association between low BMI and lung cancer risk (pooled RR 1.24; 95\% Cl: 1.20-1.27; for underweight vs. normal weight) [31]. But, this association was confined to current smokers (RR 1.31, 95\% CI: 1.10-1.57) and no statistically significant association was found in ex-smokers and never smokers (RR 1.40, 95\% CI: $0.82-2.36$ and RR 1.18, 95\% CI: 0.90-1.54, respectively) [31]. 
Table 5 Adjusted odds ratio of lung cancer by histological type according to $\mathrm{BMI}$ categories

\begin{tabular}{|c|c|c|c|}
\hline $\mathrm{BMI}\left(\mathrm{kg} / \mathrm{m}^{2}\right)^{\mathrm{a}}$ & Cases & Controls & Adjusted OR $(95 \% \mathrm{Cl})^{\mathrm{b}}$ \\
\hline \multicolumn{4}{|l|}{ Adenocarcinoma } \\
\hline Underweight & 84 & 408 & $1.17(0.89-1.54)$ \\
\hline Normal weight & 623 & 4288 & Reference \\
\hline Overweight & 290 & 2752 & $0.74(0.62-0.87)$ \\
\hline Obese & 90 & 936 & $0.65(0.50-0.85)$ \\
\hline Missing & 95 & 106 & - \\
\hline \multicolumn{4}{|c|}{ Squamous cell carcinoma } \\
\hline Underweight & 56 & 408 & $1.06(0.76-1.47)$ \\
\hline Normal weight & 445 & 4288 & Reference \\
\hline Overweight & 259 & 2752 & $0.89(0.74-1.08)$ \\
\hline Obese & 85 & 936 & $0.77(0.57-1.03)$ \\
\hline Missing & 52 & 106 & - \\
\hline \multicolumn{4}{|l|}{ Large cell carcinoma } \\
\hline Underweight & 15 & 408 & $0.98(0.55-1.76)$ \\
\hline Normal weight & 117 & 4288 & Reference \\
\hline Overweight & 54 & 2752 & $0.69(0.48-0.99)$ \\
\hline Obese & 13 & 936 & $0.49(0.26-0.92)$ \\
\hline Missing & 22 & 106 & - \\
\hline \multicolumn{4}{|l|}{ Small cell carcinoma } \\
\hline Underweight & 14 & 408 & $0.62(0.35-1.11)$ \\
\hline Normal weight & 208 & 4288 & Reference \\
\hline Overweight & 155 & 2752 & $0.90(0.70-1.15)$ \\
\hline Obese & 57 & 936 & $0.79(0.56-1.12)$ \\
\hline Missing & 39 & 106 & - \\
\hline
\end{tabular}

${ }^{a}$ Underweight (BMI < 18.5), normal weight $(18.5 \leq \mathrm{BMI}<25)$, overweight $(25 \leq$ $\mathrm{BMI}<30)$ and obese $(\mathrm{BMI} \geq 30)$

${ }^{\mathrm{b}}$ Adjusted for age, gender, study center, time elapsed, pack-years of smoking and education level

A few biological mechanisms support the plausibility for the inverse association between BMI and lung cancer risk. Environmental Geno toxicants like polycyclic aromatic hydrocarbons (PAHs) that derived from smoking and occupational exposure, are known to cause DNA damage that results in a dose-dependent risk of lung cancer [55]. Among PAHs, benzo- $\alpha$-pyrene is the most widely studied element, and its ability to induce lung tumors upon inhalation is well recognized [56]. Interestingly, studies have found inverse associations between BMI and benzo- $\alpha$-pyrene DNA adduct levels among smokers, suggesting that increased body fat impacts adduct levels, possibly by affecting the distribution of the carcinogen [57, 58]. In addition, inverse associations have been reported between BMI and levels of urinary 8-hydroxydeoxyguanosine (8-OHdG), a marker of oxidative DNA damage in smokers $[59,60]$. Brennan et al. reported that FTO genotype, a genetic marker of obesity which is related to increased BMI, was associated with a decreased risk of lung cancer [37]. On the other hand, two recent Mendelian randomization (MR) analyses for BMI and lung cancer, showed increased BMI was positively associated with lung cancer risk [38, 39]. However, the MR assumptions can be confounded by the potential pleiotropic effects of genetic variants associated with both BMI and smoking behavior [38, 39]. Recently Dik et al. conducted a large-scale genome-wide analysis of the association between BMI and DNA methylation and found increased BMI is associated with increased methylation at the HIF3A locus in blood and in adipose tissue [61]. HIF3A is an element of the hypoxia-inducible transcription factor (HIF) that controls a wide variety of cellular and physiological responses to reduced oxygen concentrations by controlling the expression of several target genes [62]. Studies have observed that HIF3A can regulate many genes associated with angiogenesis, in addition to cell survival and apoptosis [63, 64]. These observations suggest that HIF3A may play a role in lung carcinogenesis [60]. However, further molecular-epidemiological studies are needed in exploring the underlying carcinogenic mechanisms associating BMI with lung cancer risk.

The major strengths of this study include its prospective cohort-based nested case-control design, large sample size, and available information on potential confounders. As the study population was largely a nested sample from different prospective cohort studies and BMI was measured before lung cancer diagnosis, hence the possibility of selection and recall bias is minimal. In addition, we were able to perform the analyses by gender, smoking status and histological types. Our study also has some limitations. First, the use of some self-reported exposure information. However, separate analyses using measured BMI yielded similar results. In addition, previous studies have noted that even though self-reported height tends to be overestimated and weight tends to be underestimated, the self-reported values are highly correlated with the measured values [65-67]. Second, our analyses were based on self-reported cigarette smoking at baseline, and information on change in smoking habits during follow-up was not available from studies; if smoking habits varied over time, this could have had some effect on the results. However, we observed similar patterns for former and current smokers; hence it is unlikely to alter the results if current smokers became former smokers during follow-up. Third, adjustment for pack-years of smoking may not adequately control for confounding effect of cigarette smoking, thus residual confounding by smoking may still exist. Last, there was a wide range of time elapsed between BMI measurement (collected at baseline) and the date of diagnosis. However, sensitivity analysis examining this time elapsed by excluding the first 3 years of follow-up did not change risk estimates substantially. Hence, it argues 
against an effect of preclinical disease-related changes in anthropometric measures (reverse causation).

\section{Conclusions}

In conclusion, the results of this study provide additional evidence that obesity is associated with a decreased risk of lung cancer. Further biological studies are needed to address this association.

\section{Additional files}

Additional file 1: Table S1. Adjusted odds ratio of lung cancer according to BMl categories after excluding first 3 years of cases. (DOCX $15 \mathrm{~kb}$ )

Additional file 2: Figure S1. Forest plot for the association between $\mathrm{BMl}$ and lung cancer risk. (DOCX $51 \mathrm{~kb}$ )

\section{Abbreviations}

BMI: Body mass index; CARET: Carotene and Retinol Efficacy Trial; Cl: Confidence interval; EPIC: European Prospective Investigation into Cancer and Nutrition Study; OR: Odds ratio; SCHS: Singapore Chinese Health Study; SCS: Shanghai Cohort Study

\section{Acknowledgments}

Not applicable

\section{Funding}

This work was supported by the Fondation de France and Ecole doctarale de Sante Publique (ED420). The EPIC study has been supported by the Europe Against Cancer Program of the European Commission. The SCHS and SCS were supported by NCl, NIH grants U01-CA63673, UM1-CA167462 and R01CA111703. The CARET was supported by the National Institute of Health (U01 CA63673) and the Fred Hutchinson Cancer Research Center, Seattle, WA. The funding body had no role in the design of the study and collection, analysis and interpretation of data and in writing the manuscript.

\section{Availability of data and materials}

The datasets used and/or analyzed during the current study are available from the corresponding author on reasonable request.

\section{Author's contributions}

Study design: IS and CC. Analyzed data or performed statistical analysis: HS. Drafted manuscript: HS. Reviewed and commented on the manuscript: IS, $C C, J Y, L B, W K, Y G, A S, M J, P V, G G, M B$ and RH. All authors have read and approved the manuscript.

\section{Ethics approval and consent to participate}

This study was approved by the ethics committee of French National Institute of Health and Medical Research (Inserm) (IRB00003888,

FWA00005831). All subjects signed a written informed consent form.

\section{Consent for publication}

Not Applicable

\section{Competing interests}

The authors declared that they have no competing interests.

\section{Publisher's Note}

Springer Nature remains neutral with regard to jurisdictional claims in published maps and institutional affiliations.

\section{Author details}

'Cancer and Environment Group, Center for Research in Epidemiology and Population Health (CESP), INSERM, Université Paris Saclay, Université Paris-Sud, Villejuif, France. ${ }^{2}$ Division of Cancer Control and Population Sciences, University of Pittsburgh Cancer Institute, Pittsburgh, PA, USA.
${ }^{3}$ Department of Epidemiology, Graduate School of Public Health, University of Pittsburgh, Pittsburgh, PA, USA. ${ }^{4}$ Duke-NUS Medical School, Singapore, Singapore. ${ }^{5}$ Saw Swee Hock School of Public Health, National University of Singapore, Singapore, Singapore. ${ }^{6}$ Department of Epidemiology, Shanghai Cancer Institute, Shanghai, China. ${ }^{7}$ Shanghai Jiaotong University School of Medicine, Shanghai, China. ${ }^{8}$ German Institute of Human Nutrition Potsdam-Rehbrücke, Nuthetal, Germany. ${ }^{9}$ International Agency for Research on Cancer, Lyon, France. ${ }^{10}$ Department of Epidemiology and Biostatistics, the School of Public Health, Imperial College London, London, UK. ${ }^{11}$ Division of Public Health Sciences, Fred Hutchinson Cancer Research Center, Seattle, WA USA. ${ }^{12}$ Lunenfeld-Tanenbaum Research Institute, Sinai Health System, Toronto, Canada. ${ }^{13}$ Program in Epidemiology, Division of Public Health Sciences, Fred Hutchinson Cancer Research Center, Seattle, WA, USA.

Received: 23 February 2017 Accepted: 12 February 2018

Published online: 23 February 2018

\section{References}

1. GLOBOCAN 2012 v1.0, cancer incidence and mortality worldwide: IARC CancerBase no. 11 [internet]. Lyon, France: International Agency for Research on Cancer; 2013 [available from: http://globocan.iarc.fr, ].

2. Torre LA, Bray F, Siegel RL, Ferlay J, Lortet-Tieulent J, Jemal A. Global cancer statistics, 2012. CA Cancer J Clin. 2015;65(2):87-108.

3. Janssen-Heijnen ML, Coebergh JW. Trends in incidence and prognosis of the histological subtypes of lung cancer in North America, Australia, New Zealand and Europe. Lung cancer (Amsterdam, Netherlands). 2001;31(2-3): 123-37.

4. Lewis DR, Check DP, Caporaso NE, Travis WD, Devesa SS. US lung cancer trends by histologic type. Cancer. 2014;120(18):2883-92.

5. Youlden DR, Cramb SM, Baade PD. The international epidemiology of lung cancer: geographical distribution and secular trends. J Thorac Oncol: Official Publ Int Assoc Study Lung Cancer. 2008;3(8):819-31.

6. Bray Fl, Weiderpass E. Lung cancer mortality trends in 36 European countries: secular trends and birth cohort patterns by sex and region 19702007. Int J Cancer. 2010;126(6):1454-66.

7. Thun M, Peto R, Boreham J, Lopez AD. Stages of the cigarette epidemic on entering its second century. Tob Control. 2012;21(2):96-101.

8. Devesa SS, Bray F, Vizcaino AP, Parkin DM. International lung cancer trends by histologic type: male:female differences diminishing and adenocarcinoma rates rising. Int J Cancer. 2005;117(2):294-9.

9. IARC: Tobacco smoke and involuntary smoking. IARC monographs on the evaluation of carcinogenic risks to humans/World Health Organization, Int Agency Res Cancer 2004, 83:1-1438.

10. Straif K, Cohen A, Samet J: Air Pollution and Cancer: IARC Scientific Publication No. 161. International Agency for Research on Cancer, Lyon, France 2013.

11. Duan P, Quan C, Hu C, Zhang J, Xie F, Hu X, Yu Z, Gao B, Liu Z, Zheng H, et al. Nonlinear dose-response relationship between radon exposure and the risk of lung cancer: evidence from a meta-analysis of published observational studies. Eur J Cancer Prev: Official J Eur Cancer Prev Organ (ECP). 2015;24(4):267-77

12. IARC: A Review of Human Carcinogens: Arsenic, Metals, Fibres, and Dusts. Lyon, France: International Agency for Research on Cancer; 2012. IARC Monogr Eval Carcinog Risks Hum 2012, 100

13. IARC: Man-made mineral fibres and radon. IARC Monogr Eval Carcinog Risks Hum 1988, 43

14. Wang Y, Li F, Wang Z, Qiu T, Shen Y, Wang M. Fruit and vegetable consumption and risk of lung cancer: a dose-response meta-analysis of prospective cohort studies. Lung cancer (Amsterdam, Netherlands). 2015;88(2):124-30.

15. Vieira AR, Abar L, Vingeliene S, Chan DS, Aune D, Navarro-Rosenblatt D, Stevens C, Greenwood D, Norat T. Fruits, vegetables and lung cancer risk: a systematic review and meta-analysis. Ann Oncol: Official J Eur Soc Med Oncol/ESMO. 2016;27(1):81-96.

16. Basen-Engquist $K$, Chang M. Obesity and cancer risk: recent review and evidence. Curr Oncol Rep. 2011;13(1):71-6.

17. Machova L, Cizek L, Horakova D, Koutna J, Lorenc J, Janoutova G, Janout V. Association between obesity and cancer incidence in the population of the district Sumperk, Czech Republic. Onkologie. 2007;30(11):538-42.

18. Kollarova H, Machova L, Horakova D, Cizek L, Janoutova G, Janout V. Is obesity a preventive factor for lung cancer? Neoplasma. 2008;55(1):71-3. 
19. Tarnaud C, Guida F, Papadopoulos A, Cenee S, Cyr D, Schmaus A, Radoi L, Paget-Bailly $\mathrm{S}$, Menvielle G, Buemi A, et al. Body mass index and lung cancer risk: results from the ICARE study, a large, population-based case-control study. Cancer causes \& control : CCC. 2012;23(7):1113-26.

20. El-Zein M, Parent ME, Nicolau B, Koushik A, Siemiatycki J, Rousseau MC. Body mass index, lifetime smoking intensity and lung cancer risk. Int J Cancer. 2013;133(7):1721-31.

21. Calle EE, Rodriguez C, Walker-Thurmond K, Thun MJ. Overweight, obesity, and mortality from cancer in a prospectively studied cohort of U.S. adults. N Engl J Med. 2003;348(17):1625-38.

22. Kabat GC, Miller AB, Rohan TE. Body mass index and lung cancer risk in women. Epidemiol (Cambridge, Mass). 2007;18(5):607-12.

23. Kabat GC, Kim M, Hunt JR, Chlebowski RT, Rohan TE. Body mass index and waist circumference in relation to lung cancer risk in the Women's Health Initiative. Am J Epidemiol. 2008;168(2):158-69.

24. Smith L, Brinton LA, Spitz MR, Lam TK, Park Y, Hollenbeck AR, Freedman ND, Gierach GL. Body mass index and risk of lung cancer among never, former, and current smokers. J Natl Cancer Inst. 2012;104(10):778-89.

25. Bethea TN, Rosenberg L, Charlot M, O'Connor GT, Adams-Campbell LL, Palmer JR. Obesity in relation to lung cancer incidence in African American women. Cancer causes \& control : CCC. 2013:24(9):1695-703.

26. Everatt $R$, Virviciute D, Kuzmickiene I, Tamosiunas A. Body mass index, cholesterol level and risk of lung cancer in Lithuanian men. Lung cancer (Amsterdam, Netherlands). 2014;85(3):361-5.

27. Guo L, Li N, Wang G, Su K, Li F, Yang L, Ren J, Chang S, Chen S, Wu S et al: Body mass index and cancer incidence:a prospective cohort study in northern China. Zhonghua liu xing bing xue za zhi = Zhonghua liuxingbingxue zazhi 2014, 35(3):231-236.

28. Knekt P, Heliovaara M, Rissanen A, Aromaa A, Seppanen R, Teppo L, Pukkala E. Leanness and lung-cancer risk. Int J Cancer. 1991;49(2):208-13.

29. Koh WP, Yuan JM, Wang R, Lee HP, Yu MC. Body mass index and smokingrelated lung cancer risk in the Singapore Chinese health study. Br J Cancer. 2010;102(3):610-4.

30. Yang Y, Dong J, Sun K, Zhao L, Zhao F, Wang L, Jiao Y. Obesity and incidence of lung cancer: a meta-analysis. Int J Cancer. 2013;132(5):1162-9.

31. Duan P, Hu C, Quan C, Yi X, Zhou W, Yuan M, Yu T, Kourouma A, Yang K. Body mass index and risk of lung cancer: systematic review and doseresponse meta-analysis. Sci Rep. 2015;5:16938.

32. Jacobs DR Jr, Gottenborg S. Smoking and weight: the Minnesota lipid research clinic. Am J Public Health. 1981:71(4):391-6.

33. Wannamethee SG, Shaper AG, Walker M. Weight change, body weight and mortality: the impact of smoking and ill health. Int J Epidemiol. 2001;30(4): 777-86.

34. Henley SJ, Flanders WD, Manatunga A, Thun MJ. Leanness and lung cancer risk: fact or artifact? Epidemiology (Cambridge, Mass). 2002;13(3): 268-76.

35. Lam TK, Moore SC, Brinton LA, Smith L, Hollenbeck AR, Gierach GL, Freedman ND. Anthropometric measures and physical activity and the risk of lung cancer in never-smokers: a prospective cohort study. PLoS One. 2013;8(8):e70672.

36. Flegal KM, Graubard BI, Williamson DF, Cooper RS. Reverse causation and illness-related weight loss in observational studies of body weight and mortality. Am J Epidemiol. 2011;173(1):1-9.

37. Brennan P, McKay J, Moore L, Zaridze D, Mukeria A, Szeszenia-Dabrowska N, Lissowska J, Rudnai P, Fabianova E, Mates D, et al. Obesity and cancer: Mendelian randomization approach utilizing the FTO genotype. Int J Epidemiol. 2009;38(4):971-5.

38. Gao C, Patel CJ, Michailidou K, Peters U, Gong J, Schildkraut J, Schumacher FR, Zheng W, Boffetta P, Stucker I, et al. Mendelian randomization study of adiposity-related traits and risk of breast, ovarian, prostate, lung and colorectal cancer. Int J Epidemiol. 2016;45(3):896-908.

39. Carreras-Torres R, Haycock PC, Relton CL, Martin RM, Smith GD, Kraft P, Gao $C$, Tworoger S, Le Marchand L, Wilkens LR, et al. The causal relevance of body mass index in different histological types of lung cancer: a Mendelian randomization study. Sci Rep. 2016;6:31121.

40. Kanashiki M, Sairenchi T, Saito Y, Ishikawa H, Satoh H, Sekizawa K. Body mass index and lung cancer: a case-control study of subjects participating in a mass-screening program. Chest. 2005:128(3):1490-6.

41. Jee SH, Yun JE, Park EJ, Cho ER, Park IS, Sull JW, Ohrr H, Samet JM. Body mass index and cancer risk in Korean men and women. Int J Cancer. 2008; 123(8):1892-6.
42. Olson JE, Yang P, Schmitz K, Vierkant RA, Cerhan JR, Sellers TA. Differential association of body mass index and fat distribution with three major histologic types of lung cancer: evidence from a cohort of older women. Am J Epidemiol. 2002;156(7):606-15.

43. Oh SW, Yoon YS, Shin S-A. Effects of excess weight on cancer incidences depending on cancer sites and histologic findings among men: Korea National Health Insurance Corporation Study. J Clin Oncol. 2005;23(21):4742-54.

44. International Lung Cancer Consortium [http://ilcco.iarc.fr].

45. Riboli E, Kaaks R. The EPIC project: rationale and study design. European prospective investigation into cancer and nutrition. Int J Epidemiol. 1997;26: Suppl 1:S6-14

46. Riboli E, Hunt KJ, Slimani N, Ferrari P, Norat T, Fahey M, Charrondiere UR, Hemon B, Casagrande C, Vignat J, et al. European prospective investigation into cancer and nutrition (EPIC): study populations and data collection. Public Health Nutr. 2002:5(6b):1113-24.

47. Thornquist MD, Omenn GS, Goodman GE, Grizzle JE, Rosenstock L, Barnhart S, Anderson GL, Hammar S, Balmes J, Cherniack M, et al. Statistical design and monitoring of the carotene and retinol efficacy trial (CARET). Control Clin Trials. 1993;14(4):308-24.

48. Omenn GS, Goodman GE, Thornquist MD, Balmes J, Cullen MR, Glass A, Keogh JP, Meyskens FL, Valanis B, Williams JH, et al. Effects of a combination of beta carotene and vitamin a on lung cancer and cardiovascular disease. N Engl J Med. 1996;334(18):1150-5.

49. Ross RK, Yuan JM, Yu MC, Wogan GN, Qian GS, Tu JT, Groopman JD, Gao YT, Henderson BE. Urinary aflatoxin biomarkers and risk of hepatocellular carcinoma. Lancet (London, England). 1992;339(8799):943-6.

50. Yuan JM, Ross RK, Wang XL, Gao YT, Henderson BE. Yu MC: morbidity and mortality in relation to cigarette smoking in shanghai, China. A prospective male cohort study. JAMA. 1996;275(21):1646-50.

51. Hankin JH, Stram DO, Arakawa K, Park S, Low SH, Lee HP, Yu MC. Singapore Chinese health study: development, validation, and calibration of the quantitative food frequency questionnaire. Nutr Cancer. 2001;39(2):187-95.

52. Higgins JP, Thompson SG, Deeks JJ, Altman DG. Measuring inconsistency in meta-analyses. BMJ (Clin Res ed). 2003:327(7414):557-60.

53. Desquilbet L, Mariotti F. Dose-response analyses using restricted cubic spline functions in public health research. Stat Med. 2010;29(9):1037-57.

54. Bhaskaran K, Douglas I, Forbes H, dos-Santos-Silva I, Leon DA, Smeeth L. Body-mass index and risk of 22 specific cancers: a population-based cohort study of 5.24 million UK adults. Lancet (London, England). 2014;384(9945): 755-65.

55. Kim KH, Jahan SA, Kabir E, Brown RJ. A review of airborne polycyclic aromatic hydrocarbons (PAHs) and their human health effects. Environ Int. 2013;60:71-80.

56. Hecht SS. Tobacco smoke carcinogens and lung cancer. J Natl Cancer Inst. 1999;91(14):1194-210.

57. Godschalk RW, Feldker DE, Borm PJ, Wouters EF, van Schooten FJ. Body mass index modulates aromatic DNA adduct levels and their persistence in smokers. Cancer epidemiology, biomarkers \& prevention : a publication of the American Association for Cancer Research, cosponsored by the American Society of Preventive Oncology. 2002;11(8):790-3.

58. Rundle A, Madsen A, Orjuela M, Mooney L, Tang D, Kim M, Perera F. The association between benzo[a]pyrene-DNA adducts and body mass index, calorie intake and physical activity. Biomarkers : biochemical indicators of exposure, response, and susceptibility to chemicals. 2007;12(2):123-32.

59. Mizoue T, Tokunaga S, Kasai H, Kawai K, Sato M, Kubo T. Body mass index and oxidative DNA damage: a longitudinal study. Cancer Sci. 2007;98(8):1254-8.

60. Li X, Bai Y, Wang S, Nyamathira SM, Zhang X, Zhang W, Wang T, Deng Q, He M, Zhang $X$, et al. Association of body mass index with chromosome damage levels and lung cancer risk among males. Sci Rep. 2015;5:9458.

61. Dick K, Nelson CP, Tsaprouni L, Sandling JK, Aissi D, Wahl S, Meduri E, Morange PE, Gagnon F, Grallert H, et al. DNA methylation and body-mass index: a genome-wide analysis. Lancet (London, England). 2014;383(9933):1990-8.

62. Greer SN, Metcalf $J$, Wang Y, Ohh M. The updated biology of hypoxiainducible factor. EMBO J. 2012;31(11):2448-60.

63. Pasanen A, Heikkila M, Rautavuoma K, Hirsila M, Kivirikko Kl, Myllyharju J. Hypoxia-inducible factor (HIF)-3alpha is subject to extensive alternative splicing in human tissues and cancer cells and is regulated by HIF-1 but not HIF-2. Int J Biochem Cell Biol. 2010;42(7):1189-200.

64. Heikkila M, Pasanen A, Kivirikko Kl, Myllyharju J. Roles of the human hypoxiainducible factor (HIF)-3alpha variants in the hypoxia response. Cellular and molecular life sciences: CMLS. 2011;68(23):3885-901. 
65. Stommel M, Schoenborn CA. Accuracy and usefulness of BMI measures based on self-reported weight and height: findings from the NHANES \& NHIS 2001-2006. BMC Public Health. 2009;9:421.

66. Spencer EA, Appleby PN, Davey GK, Key TJ. Validity of self-reported height and weight in 4808 EPIC-Oxford participants. Public Health Nutr. 2002;5(4): 561-5.

67. Palta M, Prineas RJ, Berman R, Hannan P. Comparison of self-reported and measured height and weight. Am J Epidemiol. 1982;115(2):223-30.

Submit your next manuscript to BioMed Central and we will help you at every step:

- We accept pre-submission inquiries

- Our selector tool helps you to find the most relevant journal

- We provide round the clock customer support

- Convenient online submission

- Thorough peer review

- Inclusion in PubMed and all major indexing services

- Maximum visibility for your research

Submit your manuscript at www.biomedcentral.com/submit 